\title{
ELSŐ LÉPÉSEK A PEDAGÓGUSSÁ VÁLÁS RÖGÖS ÚTJÁN
}

\section{AZ INTÉZMÉNYVEZETŐKNEK ÉS A TESTÜLETEKNEK A KÖZNEVELÉS ÁTALAKÍTÁSÁHOZ VALÓ VISZONYÁVAL KAPCSOLATOS TAPASZTALATOK ÖSSZEGZÉSE}

\section{HÁMORI VERONIKA}

\author{
a Budapesti Fazekas Mihály Gyakorló Általános Iskola és Gimnázium \\ nyugalmazott igazgatója \\ hamoriveronika@gmail.com
}

\begin{abstract}
Jelen összegzés célja az, hogy a pályájukat az iskolákban munkavállalóként most kezdö fiatal pedagógusok felkészitését segítse azon a területen, amelyet sem a felsöoktatási intézmény keretein belül, sem a gyakorlóiskolában tanárjelöltként nem tanulhattak meg.
\end{abstract}

\section{Mi tette szükségessé azt, hogy a pedagóguspályára készülő fiatalok ismereteit szubjektívnek tekinthető elemekkel bővítsük?}

A köznevelés/közoktatás átalakításának az utóbbi években vannak olyan, rövid idő alatt végrehajtott elemei, amelyek felbolygatták az iskolák mindennapi életét, és közvetlen hatást gyakoroltak a testületek belső légkörére és az intézményvezetők személyes attitüdjére.

Az alábbi felsorolás nem teljes, és az említett változások leírása sem törekszik jogszabályi pontosságra:

- Az iskolák ,államosítása”, a müködtetés és fenntartás szétválasztása, az állami intézmények gazdasági önállóságának elvesztése. (Az intézményvezetőket közvetlenül, a testületeket közvetve érinti.)

- A pedagógusok minősítési rendszerének bevezetése, a minősítés ténye, mint új elem. (Mind az intézményvezetőkre, mind a testületekre közvetlen és erős hatást gyakorolt.)

- A minősítési rendszerrel összefüggésben a gyakornoki-mentori rendszer bevezetése. (Közvetlenül az intézményvezetők számára adódó új feladat.)

- A minősítési rendszerrel összefüggésben a mesterpedagógus szint elérésének két útja (a szakértői feladat vállalásával összekapcsolt, illetve az egyéb „mesterprogramok” vállalásával összekapcsolt), illetve ezek rövidés középtávú következményei. (Mind az intézményvezetőket, mind a pedagógusok egy részét közvetlenül érinti.) 
- A tanfelügyelet „visszavezetése” a közoktatásba, a szaktanácsadás rendszerének átalakítása. (Mind az intézményvezetőket, mind a pedagógusok egy részét közvetlenül érinti.)

- A köznevelési rendszer átalakításával összefüggésben bevezetett intézményi önértékelés rendszerének bevezetése. (Mind az intézményvezetőket, mind a pedagógusok egy részét közvetlenül érinti.)

\section{Mit kell tudni az intézményvezetőkről általában?}

Az intézményvezetés, pedagógusnak adott olyan feladat, amely a pedagógusi kompetenciák magas szintje mellett további speciális képességeket, készségeket, személyiségvonásokat kíván.

Korábban voltak olyan törekvések, amelyek - a kórházvezetéshez hasonlóan külön kívánták választani az intézmény „mendzservezetőjét” az „operatív vezetőtől", és ebben az esetben az előbbinek nem a pedagógus ismeretei, képességei és attitüdje kerültek volna előtérbe. Ezek a törekvések a köznevelési rendszer napjainkban folyó átalakításával háttérbe szorultak, mivel az erösen központosított rendszerben a „menedzselés” formálissá, sőt, lehetetlenné válik. Vagy - és ez egyik vadhajtása a rendszernek -, a „menedzselés” a jogszabályalkotókkal és a közvetlen irányítókkal való kapcsolatépítéssé degradálódik annak érdekében, hogy az intézmény fent tudja tartani egyes területeken viszonylagos önállóságát. Ez nem indokolja a „menedzservezető” különválasztását az operatív feladatokat ellátó vezetőtől, mert a rendszernek nem érdeke ez a fajta intézmény menedzselés.

Az intézményvezetőket pályázat útján nevezik ki. Ki pályázik intézményvezetôi pozícióra? Az alábbiakban igyekszem felsorolni minél több lehetséges okot, amelyek egy gyakorló pedagógust arra késztetnek, hogy pályázzon. Általában az alább felsorolt indítékok közül több is fennáll:

- A saját munkaterületén túl az intézmény müködésének egészét látja, átlátja, felismeri annak erényeit és hibáit, és van elképzelése a működés javítására vonatkozóan. Rendszerszemlélettel rendelkezik.

- Jó szervező, kreatív, aktív.

- Sikeres és eredményes tanár, aki szakmai munkájával tekintélyt szerzett a testületen belül, és tanítványai körében.

- Megfelelö, egészséges önbizalommal rendelkezik, elegendő erőt érez magában ahhoz, hogy felelősséget vállaljon az intézmény munkájáért.

- Tiszteli kollégáit, nagy meggyőzőerővel bír, és hisz az együttmüködés erejében, sőt, vannak erre vonatkozóan pozitív tapasztalatai. Kompromiszszumok kötésére alkalmas.

- Hatalomvágy vezérli, és úgy érzi, hogy a biztonságos és eredményes köznevelés megvalósításához vezető utat egyedül is képes bejárni. 
- Képesnek érzi magát arra, hogy a ráruházott hatalom eszközeivel élve a beosztottait és a rábízott gyerekeket az általa ismert és elfogadott egyetlen helyes útra terelje, kényszerítse.

- A pozíció, az intézményvezetői cím és az ezzel járó anyagi elismerés vonzza; elfogadottságának, elismerésének és az iránta tanúsított tisztelet kikényszerítésének eszközét látja a pozícióban. Ettől várja önbizalmának megfelelő szintre emelkedését.

- Pedagógusi végzettségének birtokában magasabb szintű vezetői címhez jutásra nincs lehetősége, de alkalmasnak érezné magát rá, ezért köznevelési intézmény vezetésre való pályázással „kompenzál”.

Az intézményvezetők, miután megkapták megbízásukat, szembesülnek azzal, hogy mit jelent, és mit nem jelent ez a pozíció. Ennek megfelelően igyekeznek alkalmazkodni a helyzetükhöz. Az alkalmazkodásnak számos útja-módja van. Álljon itt ezek közül néhány. (Már müködő, tehát nem frissen alapított intézmény vezetöiröl van szó, akik öröklik a müködés személyi és tárgyi feltételeit, a hagyományokat.)

- Tájékozódik, felméri, megismeri a kapott intézményi működés eddig előtte ismeretlen területeit, erősen épít a testület, benne az alacsonyabb szintü vezetők (helyettesek, munkaközösségvezetők, tagozatvezetők stb.) tapasztalataira, és megpróbálja változatlan elvek és gyakorlat alapján tovább vezetni az intézményt. Nem törekszik innovációra, új gondolatok érvényesítésére. Meg akar felelni a belsö elvárásoknak, népszerüsége érdekében.

- Mindenben meg akar felelni a külsö elvárásoknak (fenntartói, müködtetői), ezek mentén fogadja, vagy veti el az elődei által ráhagyott rendszert. Nem akar intézményen belül népszerü lenni. A külső elismerés vágya vezérli.

- Nem akar megfelelni sem külső, sem belső elvárásoknak, sőt, elutasít minden jogos, vagy jogtalan elvárást. „Perben, haragban” áll mind a munkatársaival, mind feletteseivel. Arra vágyik, hogy egyedül az ő nevéhez füződjön minden siker, és eredmény. A sikertelenség felelősségét hárítja, a külső elvártásokat, feltételeket, a testületet összetételét és a „gyerekanyagot" okolja mindenért.

- Természetesen az ,átlag” vezető egyik szélsőséget sem képviseli kizárólagosan: személyiségébe adaptálja mind a külső, mind a belső elvárásokat, és a körülmények figyelembe vételével, jó esetben alakításával egyensúlyoz a szükségszerüségek, a lehetőségek és saját elképzelései között. 


\section{Hogy viszonyultak (viszonyulnak) az intézményvezetők a legutóbbi idők változásaihoz?}

A feltett kérdésre a legegyszerübb válasz az, hogy vezetői attitüdjüknek megfelelően, azaz:

- Van vezető, aki mérlegelés nélkül elutasítja a változás minden formáját, és a maga eszközeivel gátolni igyekszik azok megvalósítását. Ennek oka - sajnos - legtöbbször politikai nézet, elkötelezettség. Közülük van, aki hangot is ad ellenérzéseinek, hirdeti ellenvéleményét, és van, aki csendben ellenáll:

o A nyíltan elutasítók egy része (és ez a jobb eset) felkészült, tájékozott a jogszabályváltozásokban, naprakészen követi azokat (ami nagyon nehéz feladat, a gyors és sürü változások miatt), és vitatja szükségességüket és a megvalósítás elöírt, követett módját. Érvei változó arányban politikaiak és szakmaiak. Ki egyik, ki másik érvrendszer fele húz. Más elutasító vezetők kevéssé felkészülten, vagy felkészületlenül vitatják és támadják a rendszert, „érveik” itt-ott hallott, olvasott, hangoztatott panelek.

o A csendben ellenállók egy része (és ez a jobb eset) felkészült, tájékozott, és saját elveivel, nézeteivel ütközteti a kapott utasításokat, és azok végrehajtását igyekszik különféle kifogásokkal „bojkottálni”, vagy legalább késleltetni, amelyekkel nem tud és nem is akar azonosulni. Más csendben ellenálló vezetők nem is próbálják megismerni a jogszabályok tartalmát, indíttatását, a végrehajtás módját. Úgy tesznek, mintha meg sem hallották volna mindazt. Vezetik tovább az intézményt a régi elvek és gyakorlat szerint, amíg falba nem ütköznek.

o Az így, vagy úgy elutasító, ellenálló vezetők tűnhetnek karakánnak, bátornak, „elvhünek”, de hozzáállásukkal (az információk visszatartása, tájékoztatás, illetve az új feladatokra való felkészítés elmulasztása) a pedagógus testületnek kárt okoz.

- Másik tipikus hozzáállás a köznevelés változásaihoz, a mindent elfogadás, az azonnali, teljes és mérlegelés nélküli elfogadása minden új elöírásnak, jogszabálynak. Az ilyen vezető nem tesz fel kérdéseket sem másnak, sem önmagának, nem próbálja megérteni az okokat, nem engedi be a kollégái kérdéseit, kétségeit, nem beszélget, nem vitatkozik, nem próbál meggyőzni: utasít, és feltétlen engedelmességet vár el, mint ahogyan ő is feltétlen engedelmességgel hajtja végre mindazt, amire utasítják. Az ilyen vezető irányítása alatt dolgozó testület megkapja a szükséges tájékoztatást, az utasításokat, azokat maradéktalanul végre is kell hajtaniuk. Nem követnek el mulasztást, nem késnek le határidőket, a testület állandó „készenlét- 
ben”, és belső felszültségtől, a retorziótól való félelemben, frusztráltan teszi a dolgát.

- A vezetők többsége - természetesen - nem a fenti szélsőséges módok valamelyikén viszonyul a változásokhoz. Okosan mérlegelve, tájékozódva és a tudását megosztva, a feltett kérdésekre választ keresve segíti a pedagógusokat.

\section{Hogy viszonyulnak a vezetők a gyakornokokhoz (a mentoráláshoz)?}

Minden vezető elemi érdeke, kiemelt felelőssége az új pedagógusok felvétele. A jogszabályi változások (benne a pedagógusok heti kötelező óraszámának emelése) sajnos nem kedveznek a testületépítésnek, mivel a kisebb heti óraszámú tárgyak tanárai csak több intézményben tudják teljesíteni a kötelező óraszámukat, így nehéz a pedagógusközösségbe integrálni öket. Többek között ezért is kiemelt fontosságú (és ezt minden vezető tudja) a pályakezdők beilleszkedésének segítése. Tapasztalat, hogy minden pedagógus számára az első tantestület a meghatározó: minden későbbit ehhez hasonlítnak, és a legtöbben itt tanulják meg a munkához kapcsolódó közösségbe tartozás élményét.

- Van vezetö, aki kijelöli a mentort a gyakornok mellé azok közül, akik elvégezték a képzést, és a későbbiekben nem foglalkozik a gyakornokkal, csak a minősítő vizsgával kapcsolatos kötelező feladatokat látja el, amikor eljön az ideje.

- Van, aki kijelöli a mentort, de formális szerepet szán neki; ő maga, (vagy helyettese) kíséri figyelemmel a gyakornok munkáját, látja el tanácsokkal, közvetlenül irányítja. A mentor akkor jut szerephez, amikor a minősítő vizsgát megelőző adminisztrációt el kell végeznie.

- Van olyan intézmény, ahol a mentorálásnak régi hagyománya van: azonos szakos kolléga, vagy a munkaközösség, vagy annak vezetője segíti a gyakornok beilleszkedését, függetlenül a kijelölt mentor személyétől. A képzést végzett mentor kijelölése ekkor is kötelező (lehet, hogy a munkaközösségben nincs is mentorképzést végzett mesterpedagógus). Ebben az esetben szorosan együtt kell müködnie a kijelölt mentornak és a gyakornok tényleges segítőinek a minősítő viuzsgára való sikeres felkészítés érdekében.

- Sok vezető tekinti a munkája meghatározó elemének a gyakornokokkal való rendszeres kapcsolattartást, azt, hogy lehetőséget teremtsenek a fiatal pedagógusnak arra, hogy feltegye kérdéseit, elmondja problémáit, tapasztalatait az intézmény egészének müködésével kapcsolatban. 


\section{Hogyan viselkedjen a pályakezdő pedagógus, amikor bekerül egy testületbe?}

Most csak olyan kérdésekre térek ki, amelyek közvetlen kapcsolatban vannak az intézményvezető személyével, személyiségével.

A pályakezdő fiatalnak felkészülten és nyitottan kell megérkeznie az intézménybe. A felkészültség ebben az összefüggésben az intézmény ismeretét jelenti: honlap, pedagógiai program, az intézmény földrajzi elhelyezkedéséből levonható következtetések ismerete (gyerekösszetétel, családi háttérre vonatkozó ismeretek). A nyitottság azt jelenti, hogy a befogadás igényével kell belépnie a testületbe.

- A testületek egésze, vagy többsége személyes kötelességének érzi, hogy ellássa információkkal az újonnan érkezőt: a szokásokról, a vezetőkről, a kollégákról. Minden információt meg kell hallgatnia, de nem szabad idő előtt állást foglalnia, kiváltképpen tilos és káros - a valahová tartozás érdekében - belépni valamely szekértáborba (a vezetőt elfogadó, és a vezetővel szemben álló csoportok valamelyikébe.).

- Minden kapott információt, tanácsot el kell raktároznia, de rosszul teszi a fiatal, ha utánozni próbál valakit, vagy valamilyen viselkedésformát. meg kell találnia önmagát a szervezetben, és csak azt megfogadni, amivel azonosulni tud, amit adaptálni tud a saját személyiségébe.

- A fiatalnak nemcsak a társas kapcsolatokra vonatkozó tanácsokra és véleményekre kell odafigyelnie, hanem arra is, hogy milyen, a teljes közoktatást, vagy az intézményt érintő kérdésekről beszélgetnek, vitatkoznak kollégái. Akkor viselkedik bölcsen, ha utána olvas a szóba kerülő jogszabályoknak, meghallgat minden tájékoztatást, elolvas minden belső csatornán érkező információt, és addig kérdez, ameddig tisztába nem kerül az összefüggésekkel. A pályakezdőt senki (vagy csak a nagyon szük látókörü ember) tartja „butának”, amiért kérdez. Neki nemcsak joga, kötelessége is minden olyan kérdést feltenni, amely szükséges önálló véleménye kialakításához. Csak a belépést követő néhány hónapban, egy évben illeti meg a helyismerettel nem rendelkezőknek járó védelem.

- A pályakezdő az intézményvezetőről kapott információkat is fogadja fenntartással. Ameddig nem ismeri meg a kollégái gondolkodását, megnyilvánulásaik motivációit, problémáikat, elfogadottságukat a testületben, népszerüségük vagy népszerütlenségük okát, nem veheti át a véleményüket akkor sem, ha szakmai munkájukat elfogadja, ha azzal rövid idö alatt kivívja tiszteletüket, megbecsülésüket.

- A gyerekek kérés nélkül is véleményt mondanak tanáraikról, igazgatójukról a fiatal pedagógusnak.(Nem szabad kikérni a véleményüket tanáraikról, sőt, lehetőség szerint el kell kerülni az olyan helyzeteket, amelyben „kibeszélik” a pedagógusokat.) Az akaratlanul és kéretlenül mégis meg- 
hallott véleményeket erős fenntartással szabad csak fogadni. A gyerek, vagy gyerekcsoport véleménye csak a csoport sajátosságainak ismeretében értékelhetö.

- Ugyanez a helyzet a szülőkkel is, akik hajlamosak az új pedagógusnak - a „bevágódás” érdekében szidni az elődöt. Ugyancsak gyakori, hogy a szülő, az életkorából fakadó felsőbbségi érzéstől vezérelve megpróbálja kioktatni a fiatal pedagógust, határozottan véleményezve munkáját, módszereit. Meg kell hallgatni (udvariasan), de sem feltétel nélkül elfogadni, sem sértettségből meggondolás nélkül visszautasítania nem szabad az ilyen véleményeket. (Nehezen kezelhető szülő esetében érdemes a mentorhoz, a szülő gyerekét szintén tanító kollégához, vagy az igazgatóhoz fordulni tanácsért, segítségért, esetleg védelemért.)

- Sajnos előfordul, hogy az igazgató a pályakezdőt próbálja felhasználni arra, hogy megtudja, mit gondolnak róla beosztottai, vagy a gyerekek. A pályakezdővel folytatott beszélgetés soha nem torzulhat „besúgássá”. Az ilyen vezetői kezdeményezés elől nagyon udvariasan, de határozottan ki kell térni.

- Arra is van példa, hogy valamely, régen az intézményben dolgozó kolléga „beárulja” a pályakezdőt az intézményvezetőnek. (Lehet az árulkodás mögött irigység, féltékenység a fiatal kolléga kora, tudása, népszerüsége miatt.) Ebben az esetben, a számonkérés során (amikor az intézményvezető számonkéri a fiatalt) az egyetlen célravezető magatartás az egyenes, őszinte beszéd a bepanaszolás tárgyára vonatkozóan. Lehet beismerni a hibát, lehet megvédeni a saját álláspontot, de nem szabad az ,árulkodó” kollégát minősíteni, esetleg bosszúból beárulni a kolléga valamely elítélhető cselekedetét vagy mondatát.

\section{Útravaló a pályakezdő pedagógus tarsolyába}

A fiatal pedagógusra vonatkozóan (is) minden helyzetben kötelező a tolerancia, a higgadt és meggondolt megnyilvánulás. Ez alól nem mentesíti sem más kolléga, sem az intézményvezető esetleg intoleráns, meggondolatlan, elfogadhatatlan magatartása. A következetesen, minden helyzetben tanúsított korrekt magatartás hosszú távon megtérül. Ez az alapja az elfogadásnak, és a tiszteletnek még azok szemében is, akiknek magatartása a fiatallal szemben kifogásolható.

\section{Összegzés}

A leírtak célja nem a pályakezdők kezdeti lelkesedésének, az új kollégáikba és vezetőikbe vetett bizalmának letörése. Épp ellenkezőleg. A napi valóság bemutatása segít abban, hogy a fiatal pedagógus ne illúziókat kergessen, és szükségszerüen rö- 
vid időn belül csalódjon, látva a tanultak és a valóság ellentmondásait, hanem kezdettől fogva nyitott szemmel és szívvel, a megértés szándékával közelítsen kollégáihoz; figyeljen, mérlegeljen, keresse az összefüggéseket, kérdezzen, ha megalapozott a véleménye, vitatkozzon. Ne passzív végrehajtó szerepre készüljön, hanem higgyen magában, készüljön nyitott, értelmiségiektől elvárható aktív részvételre az intézmény életében, a közös munkában, a meglévő értékek őrzésében, új értékek kialakításában. 